\title{
Effects of Methyl Parathion and Tri-miltox on the Mitosis of Allium cepo
}

\author{
Saeed Ahmad and Robina Yasmin \\ Institute of Pure and Applied Biology, Bahauddin Zakariya \\ University, Multan, Pakistan
}

Accepted October 17, 1991

A number of insecticides and fungicides are used extensively in the modern agricultural practices. Though the use of these chemicals has become a necessity, the frequent and indiscriminate use of these chemicals proved to have many undesirable consequences in higher plants. Plant based residues of most of these agrochemicals have been reported to be genotoxic (Stevens 1971, Epstein and Lagator 1971, Amer and Farah 1974, 1976, Mishra and Sinha 1979, Fishbein 1984, Sinha 1988). A number of workers have carried out studies to show the cytological effects of different agrochemicals on different plant species (Mousa 1982, Amer and Ali 1983, El-Khodary et al. 1989, Kumar and Sinha 1989. Sinha et al. 1989, Adam et al. 1990). In the present work two widely used agrochemicals, Methyl parathion (insecticide) and Tri-miltox (fungicide) have been studied to evaluate their ability to induce chromosomal aberrations in the meristematic root tips of Allium cepa.

\section{Material and methods}

Methyl parathion and Tri-miltox were purchased from the market. Methyl parathian belongs to organophosphorus group. This chemical is very effective against most of the sucking and chewing insects. It is very poisnous and the vergetables and fruits should not be used at least 15 days after the spray. This chemical is easily absorbed by the sprayed plant parts. Tri-miltox is an organo-poly-cupric fungicide with preventive contact action against wide range of fungal diseases. The active ingredient of this fungicide remain on the plant for a long time. Ingestion of large quantities of this chemical can cause Nausea, vomiting, diarrhea, weight loss and vertigo. In serious cases it can cause anemia.

The seeds were sown on wet filter paper in sterile petri dishes at room temp. $\left(20 \pm 4^{\circ} \mathrm{C}\right)$. Solutions of six concentrations of each of M. P. and T. M. were prepared in distilled water. The concentrations were, $0.1 \%, 0.25 \%, 0.75 \% 1.0 \%$ and $2.0 \%$.

Three treatments were used i. e., seed treatment, root treatment and root treatment with $24 \mathrm{hr}$ recovery period, thus having 3 sets of experiments. For each treatment 7 pertri dishes each with 100 sterilized seeds were used. One petri dish was used as control using distilled water and the other six for six different concentrations of the chemical.

In the first set of experiment the control seeds were sown in distilled water, while the seeds of remaining six petri dishes were sown in the different concentrations of Methyl parathion. Similar method was used for Tri-miltox. In the second set of experiment, seeds in all seven petri dishes were sown in distilled water till germination. When root tips were $3-4 \mathrm{~cm}$ long, the germinated seeds were treated with the above mentioned concentrations of the chemicals for $5 \mathrm{hr}$, then washed with distilled water and fixed in the standard fixative (3:1 alcohol: acetic acid). In the third set, 3-4 cm long germinated seeds were treated for $5 \mathrm{hr}$ with different concentrations of both chemicals separately, then washed and left in the distilled water to 


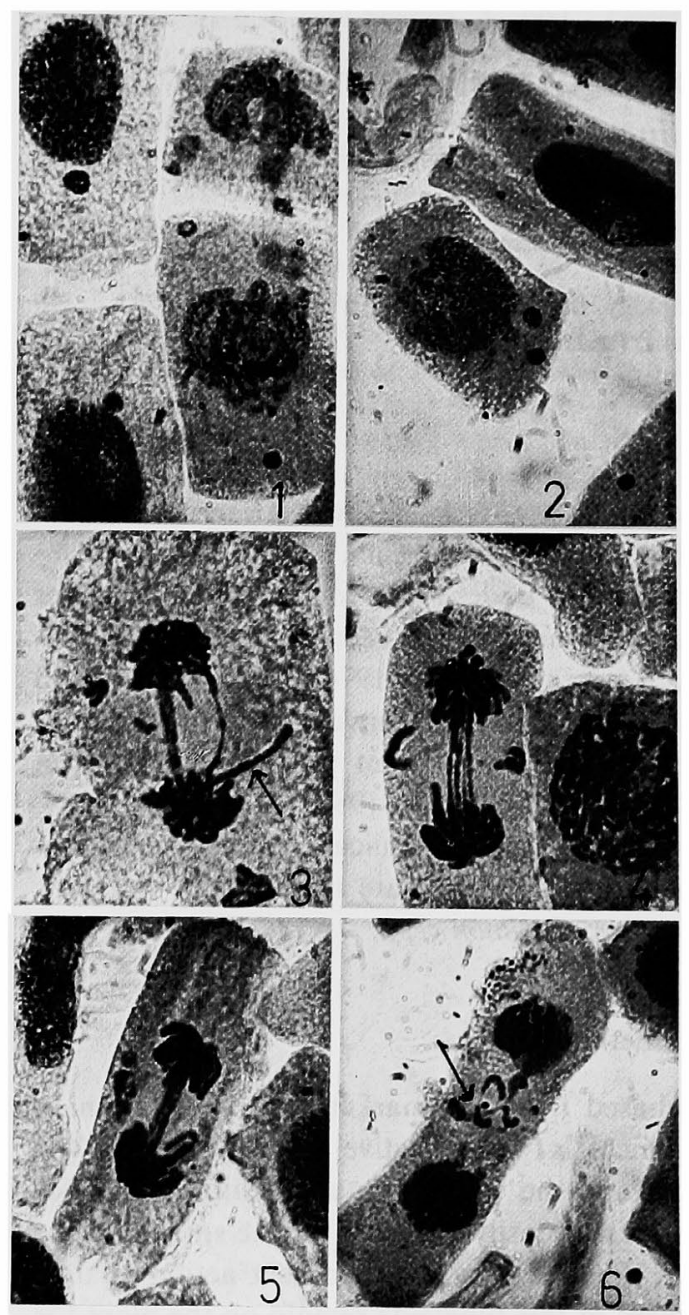

Figs. 1-6. Chromosomal aberrations induced by Methyl parathion and Tri-miltox. $\times 12001$, Formation of micronuclei at $1.0 \%$ Methyl parathion treatment. 2, Formation of micronuclei at $1.0 \%$ Tri-miltox treatment. 3, Bridge formation and chromosome fragments at $1.5 \%$ Methyl parathin treatment. One broken bridge is also visible (arrow). 4, Multiple bridge formation and laggard chromosomes at $2.0 \%$ Methyl parathion treatment. 5, Double bridge formation at $1.5 \%$ Tri-miltox treatment. 6, Laggard chromosomes or fragments at $1.5 \%$ Methyl parathian (arrow). recover for $24 \mathrm{hr}$. Then the root tips were fixed in 3:1 (alcohol: acetic acid). Roottip squashes were prepared in Aceto-orcein stain and observed under the microscope. Twenty slides for control and 20 for each chemical concentration were prepared, both for Methyl parathion and Tri-miltox. From each slide 10 fields of view were randomly selected and the total number of dividing cells, total number of abnormal cells, as well as the number of cells with micronuclei, bridges and laggard chromosomes were scored and presented as the percentages of the total dividing cells.

\section{Results}

\section{Seed treatment}

Increasing concentrations of both Methyl parathian and Tri-miltox showed a linear increase in the percentage of abnormal cells. At the lowest concentration $(0.1 \%)$, Methyl parathion and Tri-miltox produced $1.35 \%$ and $0.65 \%$ abnormal cells whereas at the highest chemical concentration $(2.0 \%)$ the percentage of abnormal cells was $2.75 \%$ and $2.59 \%$, respectively. On the whole Methyl parathion produced more aberrations than Tri-miltox at all concentrations of the chemicals. Considering the three types of aberrations individually (Table 1), highest percentage of abnormal cells were with micronuclei, then with bridges and the least with laggard chromosomes in both Methyl parathian and Tri-miltox.

\section{Root Treatment}

There was a linear incerase in total chromosomal aberrations with increasing concentrations of both the chemicals Methyl parathion and Tri-miltox. Again the percentage of abnormal cells with micronuclei

was the highest, then with bridges and the least with laggards (Table 2).

\section{Root-teatment with $24 \mathrm{hr}$ recovery period}

In both Methyl parathian and Tri-miltox total chromosomal aberrations increased steadily with the increasing concentrations of the chemicals. Individual aberrations again showed maximum percentages of cells with micronuclei, then with bridges and very few laggard chromosomes. In Methyl parathion laggards were observed in all concentrations of the chemical 
Table 1. Chromosomal aberrations induced by Methyl parathion and Tri-miltox in Allium cepa (Seed treatment)

\begin{tabular}{|c|c|c|c|c|c|}
\hline \multirow{2}{*}{$\begin{array}{c}\text { Chemicals } \\
\text { Different Conc. } \\
\text { of Methyl } \\
\text { parathian }(\%)\end{array}$} & \multicolumn{5}{|c|}{ Methyl parathion } \\
\hline & $\begin{array}{c}\text { Total number } \\
\text { of cells } \\
\text { observed }\end{array}$ & $\begin{array}{c}\text { Total } \% \text { age of } \\
\text { abnormal } \\
\text { cells }\end{array}$ & $\begin{array}{l}\% \text { age of cells } \\
\text { with } \\
\text { micronuclei }\end{array}$ & $\begin{array}{c}\% \text { age of cells } \\
\text { with } \\
\text { bridges }\end{array}$ & $\begin{array}{l}\% \text { age of cells } \\
\text { with laggard } \\
\text { chromosomes }\end{array}$ \\
\hline 0.1 & 13049 & 1.353 & 1.167 & 0.132 & 0.054 \\
\hline 0.25 & 14162 & 1.044 & 1.031 & 0.012 & - \\
\hline 0.5 & 13168 & 1.546 & 1.215 & 0.331 & - \\
\hline 0.75 & 15194 & 1.576 & 1.067 & 0.479 & 0.027 \\
\hline 1.0 & 13864 & 2.114 & 1.020 & 0.085 & 1.006 \\
\hline 2.0 & 13168 & 2.755 & 2.101 & 0.624 & 0.030 \\
\hline Chemicals & \multicolumn{5}{|c|}{ Tri-miltox } \\
\hline $\begin{array}{c}\text { Different Conc. } \\
\text { of } \\
\text { Tri-miltox }(\%)\end{array}$ & $\begin{array}{c}\text { Total number } \\
\text { of cells } \\
\text { observed }\end{array}$ & $\begin{array}{c}\text { Total \% age of } \\
\text { abnormal } \\
\text { cells }\end{array}$ & $\begin{array}{l}\% \text { age of cells } \\
\text { with } \\
\text { micronuclei }\end{array}$ & $\begin{array}{c}\% \text { age of cells } \\
\text { with } \\
\text { bridges }\end{array}$ & $\begin{array}{l}\% \text { age of cells } \\
\text { with laggard } \\
\text { chromosomes }\end{array}$ \\
\hline 0.1 & 8992 & 0.659 & 0.351 & 0.142 & 0.017 \\
\hline 0.25 & 7284 & 1.013 & 0.676 & 0.420 & 0.193 \\
\hline 0.5 & 12021 & 1.392 & 1.152 & 0.175 & 0.065 \\
\hline 0.75 & 9648 & 1.848 & 1.390 & 0.293 & 0.165 \\
\hline 1.0 & 8946 & 1.864 & 1.203 & 0.411 & 0.250 \\
\hline 2.0 & 10590 & 2.590 & 2.184 & 0.317 & 0.089 \\
\hline
\end{tabular}

Table 2. Chromosomal aberrations induced by Methyl parathion and Tri-miltox in Allium cepa (Root treatment)

\begin{tabular}{|c|c|c|c|c|c|}
\hline \multirow{2}{*}{$\begin{array}{l}\text { Chemicals } \\
\text { Different Conc. } \\
\text { of Methyl } \\
\text { parathian }\end{array}$} & \multicolumn{5}{|c|}{ Methyl parathion } \\
\hline & $\begin{array}{l}\text { Total number } \\
\text { of cells } \\
\text { observed }\end{array}$ & $\begin{array}{c}\text { Total \% age of } \\
\text { abnormal } \\
\text { cells }\end{array}$ & $\begin{array}{l}\% \text { age of cells } \\
\text { with } \\
\text { micronuclei }\end{array}$ & $\begin{array}{c}\% \text { age of cells } \\
\text { with } \\
\text { bridges }\end{array}$ & $\begin{array}{l}\text { \% age of cells } \\
\text { with laggard } \\
\text { chromosomes }\end{array}$ \\
\hline 0.1 & 12004 & 0.475 & 0.398 & 0.076 & - \\
\hline 0.25 & 11309 & 0.721 & 0.712 & 0.033 & - \\
\hline 0.5 & 10050 & 1.251 & 1.147 & 0.192 & - \\
\hline 0.75 & 12936 & 1.200 & 1.190 & 0.061 & - \\
\hline 1.0 & 10715 & 1.324 & 1.079 & 0.245 & - \\
\hline 2.0 & 12097 & 2.504 & 2.226 & 0.277 & - \\
\hline Chemicals & \multicolumn{5}{|c|}{ Tri-miltox } \\
\hline $\begin{array}{l}\text { Different Conc. } \\
\text { of } \\
\text { Tri-miltox }(\%)\end{array}$ & $\begin{array}{l}\text { Total number } \\
\text { of cells } \\
\text { observed }\end{array}$ & $\begin{array}{l}\text { Total \% age of } \\
\text { abnormal } \\
\text { cells }\end{array}$ & $\begin{array}{l}\% \text { age of cells } \\
\text { with } \\
\text { micronuclei }\end{array}$ & $\begin{array}{c}\% \text { age of cells } \\
\text { with } \\
\text { bridges }\end{array}$ & $\begin{array}{l}\% \text { age of cells } \\
\text { with laggard } \\
\text { chromosomes }\end{array}$ \\
\hline 0.1 & 11303 & 0.441 & 0.424 & 0.017 & - \\
\hline 0.25 & 13078 & 0.550 & 0.410 & 0.140 & - \\
\hline 0.5 & 14981 & 1.235 & 1.194 & 0.053 & 0.006 \\
\hline 0.75 & 12211 & 1.299 & 1.219 & 0.080 & - \\
\hline 1.0 & 13642 & 1.421 & 1.063 & 0.358 & - \\
\hline 2.0 & 12605 & 1.856 & 1.553 & 0.303 & - \\
\hline
\end{tabular}

except at $0.1 \%$, whereas in Tri-miltox laggards were observed at only 3 concentrations i. e., $0.25 \%, 0.5 \%$ and $2.0 \%$. (Table 3 ). Total chromosomal aberrations produced by three differnt treatments of Methyl parathion showed that seed treatment produced the highest percentage of chromosomal aberrations followed by root treatment and the lowest percentage of aberrations was observed in root treatment with recovery period. Comparing the results at the highest chemical concentration of $2.0 \%$, seed tratment, root treatment and root treatment 
with $24 \mathrm{hr}$ recovery period had $2.75 \%, 2.5 \%$ and $1.6 \%$ chromosomal aberrations, respectively. In the case of Tri-miltox, seed treatment again produced the highest percentage of chromosomal aberrations as compared to root treatment and root treatment with recovery period. The later two treatments have about the same percentage of chromosomal aberrations. Comparing the affects of two chemicals, Methyl parathian produced more chromosomal aberrations than Tri-miltox at different concentrations of the chemical.

\section{Discussion}

In the present work, treatment with Tri-miltox and Methyl parathian produced an increased number of abnormal mitotic cells as compared to control material. There was a gradual increase in the percentage of chromosomal aberrations with the increase of chemical concentration. These results are in line with the results of many workers who worked with different chemicals on different plant materials such as Reddy and Rao (1969), Amer and Farah (1979), Al-Najjar and Soliman (1980), Kaur and Grover (1985), Mohan (1975), Paraksh and Lakshmi (1980) and Rabindra (1989). Methyl parathian produced comparatively more chromosomal aberrations than Tri-miltox.

Table 3. Chromosomal aberrations induced by Methyl parathion and Tri-miltox in Allium cepa (Root treatment with 24 hours recovery period)

\begin{tabular}{|c|c|c|c|c|c|}
\hline \multirow{2}{*}{$\begin{array}{c}\text { Chemicals } \\
\text { Different Conc. } \\
\text { of Methyl } \\
\text { parathian }(\%)\end{array}$} & \multicolumn{5}{|c|}{ Methyl parathion } \\
\hline & $\begin{array}{l}\text { Total number } \\
\text { of cells } \\
\text { observed }\end{array}$ & $\begin{array}{l}\text { Total \% age of } \\
\text { abnormal } \\
\text { cells }\end{array}$ & $\begin{array}{l}\% \text { age of cells } \\
\text { with } \\
\text { micronuclei }\end{array}$ & $\begin{array}{c}\% \text { age of cells } \\
\text { with } \\
\text { bridges }\end{array}$ & $\begin{array}{l}\% \text { age of cells } \\
\text { with laggard } \\
\text { chromosomes }\end{array}$ \\
\hline 0.1 & 9835 & 0.287 & 0.181 & 0.099 & - \\
\hline 0.25 & 10262 & 0.556 & 0.335 & 0.210 & 0.011 \\
\hline 0.5 & 11253 & 0.601 & 0.348 & 0.209 & 0.044 \\
\hline 0.75 & 13418 & 0.951 & 0.850 & 0.064 & 0.037 \\
\hline 1.0 & 15409 & 1.294 & 1.091 & 0.139 & 0.064 \\
\hline 2.0 & 16275 & 1.622 & 1.477 & 0.113 & 0.031 \\
\hline Chemicals & \multicolumn{5}{|c|}{ Tri-miltox } \\
\hline $\begin{array}{c}\text { Different Conc. } \\
\text { of } \\
\text { Tri-miltox }(\%)\end{array}$ & $\begin{array}{c}\text { Total number } \\
\text { of cells } \\
\text { observed }\end{array}$ & $\begin{array}{c}\text { Total \% age of } \\
\text { abnormal } \\
\text { cells }\end{array}$ & $\begin{array}{l}\% \text { age of cells } \\
\text { with } \\
\text { micronuclei }\end{array}$ & $\begin{array}{c}\% \text { age of cells } \\
\text { with } \\
\text { bridges }\end{array}$ & $\begin{array}{l}\% \text { age of cells } \\
\text { with laggard } \\
\text { chromosomes }\end{array}$ \\
\hline 0.1 & 12697 & 0.669 & 0.605 & 0.044 & - \\
\hline 0.25 & 14931 & 0.802 & 0.671 & 0.053 & 0.077 \\
\hline 0.5 & 14446 & 0.990 & 0.754 & 0.063 & 0.133 \\
\hline 0.75 & 12199 & 0.823 & 0.610 & 0.213 & - \\
\hline 1.0 & 11523 & 1.673 & 1.527 & 0.145 & - \\
\hline 2.0 & 15127 & 1.849 & 1.776 & 0.065 & 0.006 \\
\hline
\end{tabular}

Bridge formation, laggard chromosomes and micronuclei, were the main types of chromosomal abnormalities induced by chemical treatment. The bridges may be formed due to the breakage and reunion of chromosomes (Permjit and Grover 1985). Anaphase bridges in meiosis were also recorded by Wuu and Grant (1967), Amer and Ali (1974) in Vicia faba, Srihari and Madhusuthana (1982), Devadas et al. (1986) in Capsicum annuum. The formation of small fragments can be attributed to the chromosomal breakages due to the effect of chemical. Soliman and Al-Najjar (1980) has also reported fragments in Vicia faba after chemical treatment. The lagging chromosomes can be attributed to the delayed terminalization, stickiness of chromosome ends, or because of the failure of chromosomal movement (Permjit and and Grover 1985). Chaghtai (1979) used different concentration of EMS and observed the 
chromosomal breakage in two varieties of onion. Ajey (1988) used some chlorinated pesticides and reported partial or entre inactivation of spindle mechanism followed by scattering of chromosomes. He proposed that the cell division is energy dependent process and thereby the movement of chromosomes mainly depends upon the energy generated system. The pesticide treatment disturbs the respiratory pathways resulting in low accumulation of energy containing and other essential compounds i. e.; ATP, sugar and protein molecules etc. The sticky nature of chromosomes may be due to delay in chromosome movement by pesticides treatment. Thus the chromosomes could not reach to the poles and remained scattered in the cytoplasm and appeared condensed and sticky (Ajay 1988). However, McGill et al. (1974) and Klasterska et al. (1974) suggested that chromosomal stickiness arises due to improper folding of chromosome fiber into single chromatid and chromosomes. Soheir (1989) reported a high level of chromosomal stickiness in metaphase stage after herbicide treatment. Similar results were obtained by other workers (Amer and Farah 1985, El-Bayoumi et al. 1987). Laggards in metaphase and telophase stages were also observed in Allium cepa roots after chemical treatment (Soheir 1989). Another interesting abnormality noticed in the present study is the appearance of anaphase and telophase bridges involving one or more chromosomes. The bridge formation can be due to the general stickiness of the chromosomes at metaphase stage, or because of breakage and reunion of chromosomes. Similar type of abnormality was also observed in the mitosis of Vicia faba after treatment with the organophosphorus insecticide (Amer and Farah 1979, 1983, 1985). In addition to the above mentioned abnormalities interphase cells with micronuclei were also observed. Such micronuclei may originate from lagging chromosomes or from acentric fragments which were observed in mitotic stages.

\section{Summary}

Treatment of Alium cepa seeds with different concentrations of Methyl parathion (insecticide) and Tri-miltox (fugicide) induced different types of chromosomal aberrations, such as micronuclei, chromosomal fragments, laggard chromosomes, single and multiple bridge formation. Maximum number of cells were observed with micronuclei, then with bridges and the minimum with laggard chromosomes. Methyl parathion produced comparatively more chromosomosomal aberrations than Tri-miltox. Comparing the three treatments applied, seed treatment produced maximum chromosomal aberrations, and the root treatment with recovery period produced the minimum chromosomal aberrations with the root treatment occupying the intermediate position.

\section{References}

Adam, Z. M., Ebab, F. A. and El-Shaikh, I. A. 1990. Alterations in nucleic acids, protein content and mitotic division of Vicia faba root tip cells as effected by Malathion and Tamaron insecticides. Cytologia 55: 349-355.

Ajay, K. J. and Sarbhoy, R. K. 1988. Cytogenetic studies on the effect of some chlorinated pesticides. Cytologia 53: 427-436.

Al-Najjar, N. R. and Soliman, A. S. 1980. Cytological effects of fungicides. 1. Mitotic effect of vitavax-200 and Dithane S-60 on wheat and two related species. Cytologia 45: 163-168.

Amer, S. M. and Farah, O. R. 1974. Cytological effects of pesticides VI. Effects of pesticides "Rogor" on the mitosis of Vicia faba and Gossypium barbadense. Cytologia 39: 507-514.

— and - 1976. Cytological effects of pesticides. VIII. Effects of carbonate pesticides "IPC", "Rogor" and "Duphar" on Vicia faba. Cytologia 41: 597-606.

- and - 1979. Cytological effects of pesticides. IX. Effects of the phosphonothioate insecticide "Leptophos" on Vicia faba. Cytologia 44: 907-913.

- and - 1983. Cytological effects of pesticides XII. Effects of the phosphonothioate insectcide "Dursban" 
on the mitosis of Vicia faba. Cytologia 48: 27-33.

- and - 1985. Cytological effects of pesticides XV. Effect of the insecticide "Methamidophos" on root mitosis of Vicia faba. Cytologia 50: 521-526.

— and Ali, E. M. 1983. Cytological effects of pesticides XIV. Effect of insecitice "Dipterex" and "Trichlorophan" on Vicia faba L. Cytologia 48: 761-770.

Chaghtai, S. A. Zia, H. and Deeba, A. 1979. Chromosomal behavior at mitosis in the EMS treated progenies of two varieties of onion. Biologia 25: 123-126.

Devadas, N. M., Rajan, V. and Subash, K. 1986. Comparative mutagenicity of four organophosphorus insecticides in meiotic system of red peper. Cytologia 51: 645-653.

Epstein, S. S. and Lagator, M. S. 1971. The Mutagenicity of Pesticides. Concepts and evolution. M. I. T Press, Cambridge, pp. 220.

Fishbein, L. 1984. Mutagens and carcinogens in environment. Genetics New Frontiers, Vol. 3 [(Proc. XI Int. Cong. Genetics) Oxford and IBH Publishers, New Delhi: 3-42.

Kaur, P. and Grover, I. S. 1985. Cytological effects of some organophosphorus pesticides. I. Mitotic effects. Cytologia 50: 187-197.

Klasterska, I., Naterjan, A. T. and Ramel, C. 1976. An interpretation of the origin of subchromatid aberrations and chromosome stickiness as a category of chromatid aberration. Hereditas 83: 153-162.

Kumar, D. and Sinha, S. P. 1989. Search of genotoxic sub-threshold dose of Malathion. Perspectives in cytology and Genetics vol 6 (Edt. G. K. Manna) 729-732.

Mishra, G. M. and Sinha, S. P. 1979. Effects of Malathion on mitotically dividing onion root tip cells. Ind. J. Exp. Biol. 17: 716-717.

McGill, M., Pathak, S. and Hsu, T. C. 1974. Effects of Ethidium bromide on mitosis and chromosome. Chromosoma 47: 157-167.

Mohan, S. T. 1975. Cytological effects of fungicides "Plantvax" and "Vitacax" on somatic cells of Allium cepa L. Curr. Sci. 44: 813-814.

Mousa, M. 1982. Effects of some herbicides on mitotic activity and mitotic aberrations in the root tips of onion. Egyptian J. Genet. Cytol. 11 : 193-207.

Permjit, K. and Grover, I. S. 1985. Cytological effects of some organophosphorus pesticides. II. Meiotic effects. Cytologia 50: 199-211.

Parakash, N. S. N. and Lakshmi, I.I. 1988. Cytological effects of agricultural chemicals II. Effects of fungicide "Bavistin and Deltan" on Capsicum annuum. Cytologia 53: 709-815.

Rabindra, K., Rupak, C. and Ranajit, M. 1989. Cytological effects of Phosalone or root meristem of Allium cepa. Cytologia 54: 429-435.

Reddy, M. V. and Rao, B. V. 1969. The cytological effects of insecticides (Dimecron-100 and Rogor-40) on Vicia faba. Cytologia 34: 408-417.

Sinha, S. P. 1988. Genotoxicity of pesticides; Perspectives in cytology and genetics. Vol. 6. Ed. G. K. Manna. New Delhi.

Sinha, R. K., Chaudhry, R. and Malick, R. 1989. Cytological effects of Phosalone on root meristem of Allium cepa L. Cytologia 54: 429-435.

Soheir, E., Antoinette, H. and Atif, H. 1989. Cytological effects of Herbicide Garlon-4 on root mitosis of Allium cepa. Cytologia 54: 465-472.

Soliman, A. S. and Al-Najair, N. R. 1980. Cytological effects of vitavax-200 and Dithane S-60 in meiotic cells of Wheat and two related species. Cytologia 45: 169-175.

Srihari, R. S. and Madhusudhana, R. G. 1981. Cytogenetic effects of agricultural chemicals I. Effects of insecticides BHC and Nuvacron on chromosomal mechanism in relation to yield and yield components in Capsicum annuum. Cytologia 46: 699-707.

Stevens, R. W. 1971. Pesticides in the Environment. Marcel Dekker Inc. New York Vol. 1. Part-II, 310399.

Wuu, K. D. and Grant, W. F. 1967. Chromosomal aberrations induced by pesticides in meiotic cells of Barley. Cytologia 32: $31-41$. 